\title{
APLIKASI VOTING PEMILIHAN KETUA ORGANISASI SISWA INTRA SEKOLAH (OSIS) PADA MA NURUL IHSAN NW TILAWAH BERBASIS WEB
}

\author{
${ }^{1}$ Mohammad Taufan Asri Zaen, ${ }^{2}$ Ryadi Putra \\ Program Studi Sistem Informasi \\ Sekolah Tinggi Manajemen Informatika dan Komputer (STMIK) Lombok \\ Jln. Basuki Rahmat No.105 Praya Lombok Tengah \\ 10panzain@gmail.com, 2poetrastilo@gmail.com
}

\begin{abstract}
In the world of education, technology plays very important role to support the teaching and learning process and activities in the school, but not all of the process activities accommodated by the development of technology. The process of election of OSIS MA Nurul Ihsan NW Tilawah, a system that everything is done still conventional, all the process is done manually and it is less effective and efficient. Voting (E-Voting) applications are considered to be more effective and more efficient because all of the process is computerized, making it easier for users to choose candidates, simplify the vote counting process and the results of the election can be known quickly and accurately.

The manufacture and application design of voting election of the OSIS on MA Nurul Ihsan NW Tilawah based website was built using development methods system development life cycle (SDLC), programming languages PHP and using MySQL database. The data that will be managed in the system are committee data, voter or student data, candidate data or candidate OSIS with the registration process and selection process. The output of this application design is the voter data report, the candidate data report and the voting voice data report.

This voting application at MA Nurul Ihsan NW Tilawah is expected to facilitate the process of electing the student council president, and giving voting results that are accurate, fast and reliable and can reduce the number of students who do not vote and will not interfere with the teaching and learning process.
\end{abstract}

Keywords: OSIS, E-voting, SDLC, PHP, MySQL

\begin{abstract}
Abstrak
Dalam dunia pendidikan, teknologi berperan sangat penting untuk menunjang proses belajar mengajar dan kegiatan yang ada di sekolah, namun belum semua proses kegiatan terakomodir oleh perkembangan teknologi. Proses pemilihan ketua OSIS MA Nurul Ihsan NW Tilawah, sistem yang dilakukan semuanya masih konvensional, semua proses dilakukan secara manual dan hal ini dirasa kurang efektif dan efisien. Aplikasi Voting/Electronic Voting (E-Voting) dianggap lebih efektif dan lebih efisien karena semua proses secara terkomputerisasi, memberikan kemudahan bagi pengguna untuk memilih calon, mempermudah dalam proses penghitungan suara dan hasil pemilihan bisa langsung diketahui secara cepat dan akurat.

Pembuatan dan perancangan aplikasi voting pemilihan ketua OSIS pada MA Nurul Ihsan NW Tilawah berbasis web dibangun menggunakan metode pengembangan system development life cycle (SDLC), bahasa pemrograman PHP dan menggunakan database MySQL. Data yang akan dikelola didalam sistem tersebut adalah data panitia, data pemilih atau siswa, data kandidat atau calon ketua OSIS dengan proses pendaftaran dan proses pemilihan. Output dari perancangan aplikasi ini adalah laporan data pemilih, laporan data kandidat dan laporan data suara pemilihan.

Aplikasi Voting di MA Nuruh Ihsan NW Tilawah ini diharapkan mempermudah dalam proses pemilihan ketua OSIS, dan memberikan hasil voting yang akurat, cepat dan terpercaya serta bisa mengurangi angka siswa yang tidak memilih dan tidak akan mengganggu proses belajar mengajar

Kata kunci: OSIS, E-voting, SDLC, PHP, MySQL
\end{abstract}




\section{Pendahuluan}

Voting adalah kegiatan yang sangat menentukan pada setiap perhelatan pemilihan, banyak varian kepentingan yang harus diakomodir di dalamnya, terutama bagaimana sistem pemilihan itu dilaksanakan, bagaimana regulasi atau peraturan yang disepakati dan menjadi aturan main, siapa yang dipilih dan siapa yang berhak memilih. Tidak kalah pentingnya adalah bagaimana proses pemungutan suara dapat menjamin azas langsung, umum, bebas dan rahasia serta bagaimana hasil penghitungan suara dapat berlangsung jujur, transparan, dapat diakses oleh publik. Selama ini, voting dilaksanakan secara centang atau coblos pada kertas suara menjadi pilihan dalam penyelenggaraan pemilu. Metode ini dinilai masih sangat konvensional di tengah kemajuan teknologi dan informasi, memiliki kelemahan dari aspek efisiensi dan efektifitas. Pada proses pemilihan Ketua Organisasi Siswa Intra Sekolah (OSIS) kebanyakan juga masih dilakukan secara manual, hal ini dirasa kurang efektif dengan berkembangnya teknologi.

Sistem pemilihan ketua OSIS pada MA Nurul Ihsan NW Tilawah masih menggunakan cara konvensional, dimana siswa dan siswi harus menuju bilik suara, mencoblos atau mencontreng salah satu kandidat ketua OSIS serta panitia harus menghitung hasil dari kertas suara satu persatu. Sistem pemilihan konvensional memiliki beberapa kelemahan diantaranya memerlukan biaya lebih untuk menggunakan kertas, tinta, bilik suara, lambatnya proses penghitungan suara dan terkadang kurang akuratnya hasil penghitungan suara, memerlukan tempat yang luas, serta memerlukan waktu yang lebih lama.

Untuk mengatasi hal tersebut maka dibangun sebuah aplikasi untuk melaksanakan voting berbasis web yang diharapkan memberikan hasil voting yang akurat, cepat dan terpercaya serta bisa mengurangi angka siswa yang tidak memilih dan tidak akan mengganggu proses belajar mengajar.

\section{Tinjauan Pustaka}

Yuniarti, (2015), dalam penelitiannya tentang aplikasi pendaftaran dan pemilihan pengurus osis menyatakan aplikasi yang dibangun dapat mempermudah user dalam penggunaan, membantu panitia (admin) dalam mengelola data dan mempersiapkan waktu kegiatan pemilihan yang akan diselenggarakan disekolah, yang lebih efesien dan efektif, dan mampu memberikan alternatif serta membantu pihak sekolah dalam pemilihan pengurus OSIS.

Adhi dan Harjono, (2013), dalam penelitiannya tentang SI E-Voting berbasis sms gateway menyatakan bahwa E-Voting ini dapat mempermudah untuk melakukan pemilihan ketua osis dan ketua kelas dengan cukup mengirimkan sms, mampu menghasilkan sistem pengolahan hasil pemungutan suara dengan tepat, cepat, akurat dan transparan, serta bisa mengurangi angka siswa yang tidak memilih dan tidak akan mengganggu proses belajar mengajar.

Yusriannur, (2012), dalam penelitiannya tentang aplikasi E-Voting berbasis web menyatakan dengan E-Voting diharapkan minat mahasiswa untuk berpartisipasi memberikan suara semakin banyak dan proses pengolahan suara semakin cepat. Sistem ini mempermudah mahasiswa dalam memberikan hak suaranya dimanapun berada tanpa harus mendatangi kampus dan membantu panitia dalam pemrosesan suara yang masuk secara cepat, tepat dan efisien

\section{3. $\quad$ Voting}

Voting adalah kegiatan yang sangat menentukan pada setiap perhelatan pemilihan, banyak varian kepentingan yang harus di akomodir di dalamnya, terutama bagaimana sistem pemilihan itu dilaksanakan, bagaimana regulasi atau peraturan yang disepakati dan menjadi aturan main, siapa yang dipilih dan siapa yang berhak memilih. Tidak kalah pentingnya adalah bagaimana proses pemungutan suara dapat menjamin azas langsung, umum, bebas dan rahasia serta bagaimana hasil penghitungan suara dapat berlangsung jujur, transparan, dapat diakses oleh publik. Selama ini, voting secara centang atau coblos kertas suara menjadi pilihan dalam penyelenggaraan pemilu dan pemilukada di tanah air. Metode ini oleh banyak kalangan dinilai masih sangat konvensional di tengah kemajuan teknologi dan informasi, memiliki kelemahan dari aspek efisiensi dan efektifitas 


\section{SDLC}

Metode pengembangan yang digunakan pada perancangan sistem ini adalah System Development Life Cycle (SDLC) merupakan pengembangan/rekayasa sistem informasi (system development) dan atau perangkat lunak (software engineering) dapat berarti menyusun sistem/ perangkat lunak yang benar-benar baru atau yang lebih sering terjadi yaitu menyempurnakan yang telah ada sebelumnya (Adi Nugroho, 2010)

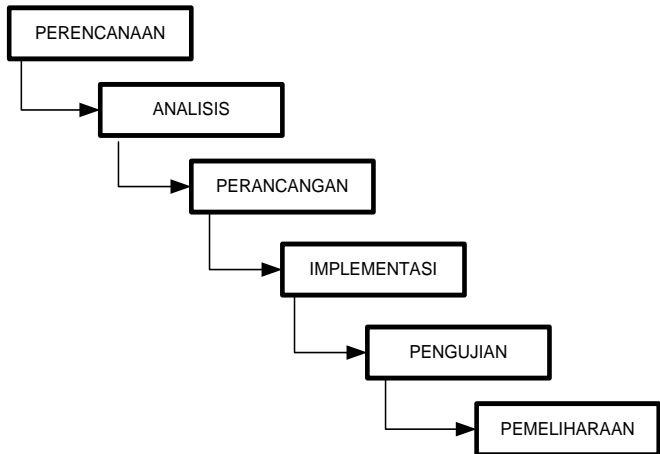

Gambar 1. Kerangka Kerja Pengembangan Sistem Informasi

\section{Analisa dan Perancangan}

\section{A. Sistem Yang Berjalan}

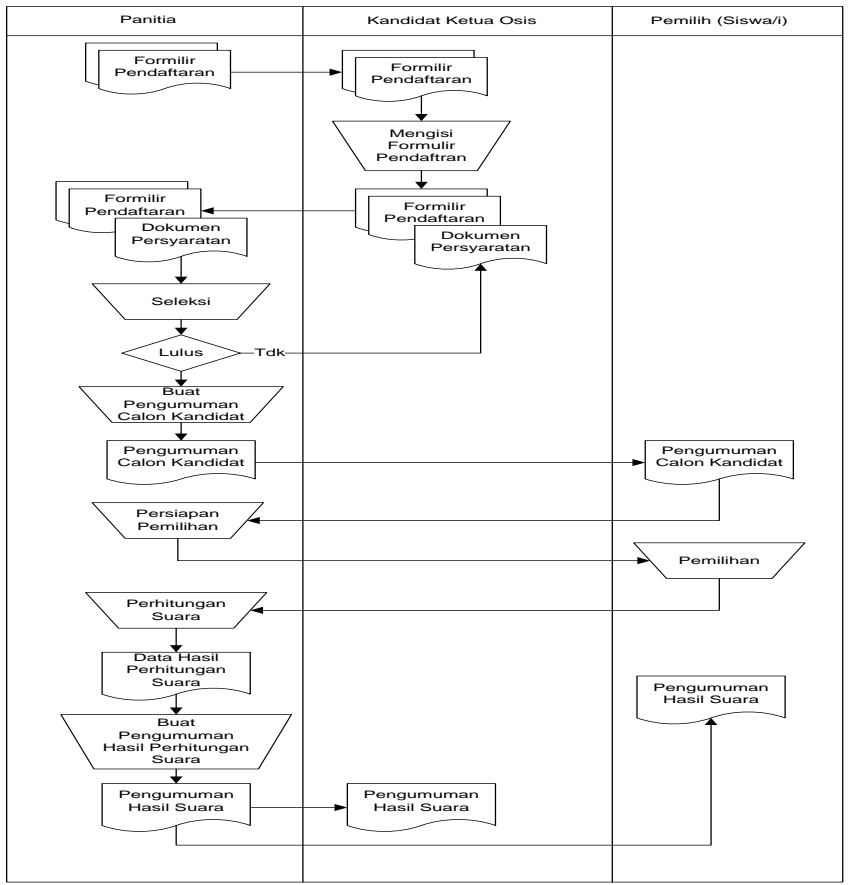

Gambar 2. Flowmap Sistem Pemilihan Ketua OSIS Yang Berjalan
1. Panitia menyerahkan formulir pendaftran kepada kandidat ketua OSIS, kemudian di isi dan diserahkan ke panitia beserta dokumen pendaftarannya.

2. Panitia menyeleksi formulir pendaftran beserta dokumen persyaratanya, apa bila tidak sesuai maka akan dikembalikan lagi dan apabila sesuai maka panitia akan membuat pengumuman calon kandidat ketua OSIS

3. Selanjutnya panitia mempersiapkan alat dan bahan serta waktu pemilihan, pada hari dan waktu yang telah ditentukan pemilih akan melakukan proses pemilihan.

4. Dari hasil pemilihan akan dilakukan proses perhitungan oleh panitia, berdasarkan hasil perhitungan tersebut akan dibuat pengumuman hasil perhitungan.

\section{B. Use Case Diagram}

Use Case Diagram digunakan untuk mengambarkan apa yang dilakukan oleh sistem, serta interaksi antara aktor dengan sistem. Use case Diagram aplikasi voting pemilihan ketua OSIS pada MA Nurul Ihsan NW Tilawah.

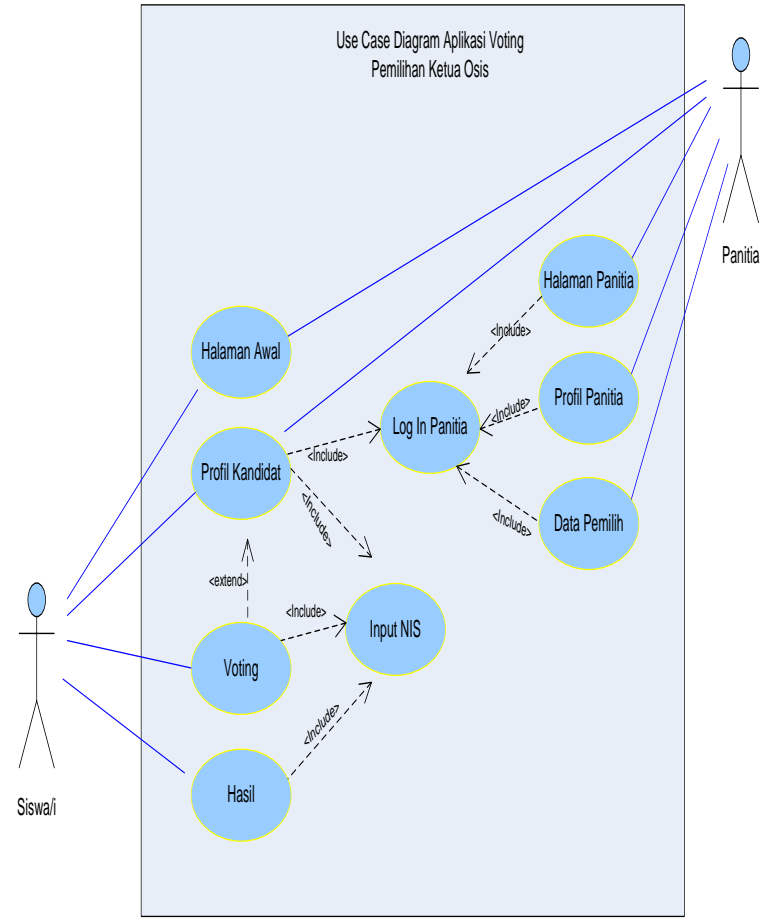

Gambar 3. Use Case Diagram Aplikasi Voting Pemilihan Ketua OSIS Usulan

\section{Activity Diagram}


Activity diagram lebih menggambarkan proses-proses dan alur aktivitas dalam sistem yang sedang dirancang. Berikut merupakan activity diagram dari use case aplikasi voting pemilihan ketua OSIS.

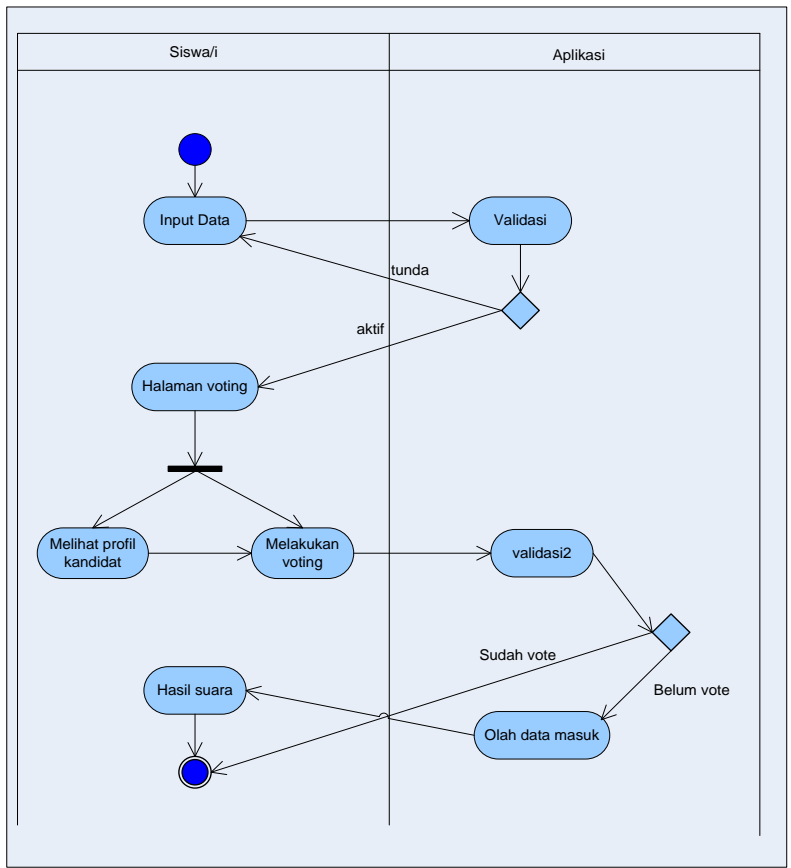

Gambar 4. Activity Diagram Aplikasi Voting

\section{Sequence Diagram}

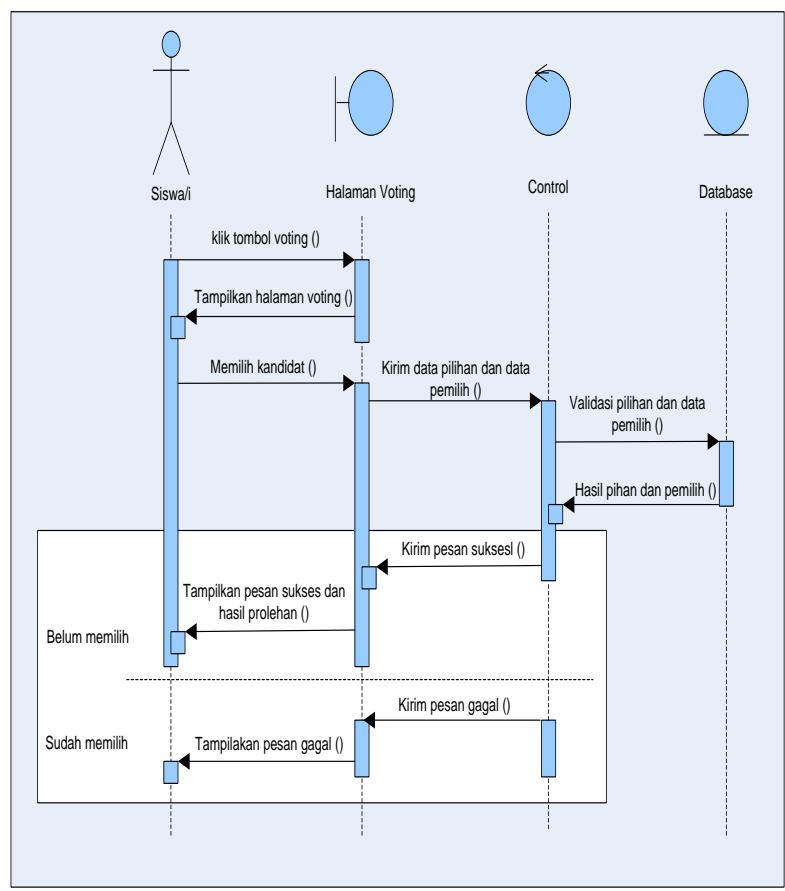

Gambar 5 Sequence Diagram Aplikasi Voting
Gambar 5 menjelaskan tentang rangkaian proses pengolaha data pemilihan yang dilakukan oleh siswa/ i sebagai aktor. Proses dimulai ketika siswa/ i melakukan langkah untuk login masuk ke sistem, kemudian sistem akan merespon dengan validasi data yang dimasukkan ketika login. Kemudian sistem akan menampilkan halaman menu awal. Selanjutnya siswa akan memilih menu kandidat ketua OSIS, sistem menampilkan list data kandidat yang sudah di masukkan dalam sistem dan database. Kemudian melakukan proses pemilihan ketua OSIS dengan memilih salah satu button, hingga sistem akan melakukan validasi data untuk menjaga data tersimpan di database.

\section{E. Class Diagram}

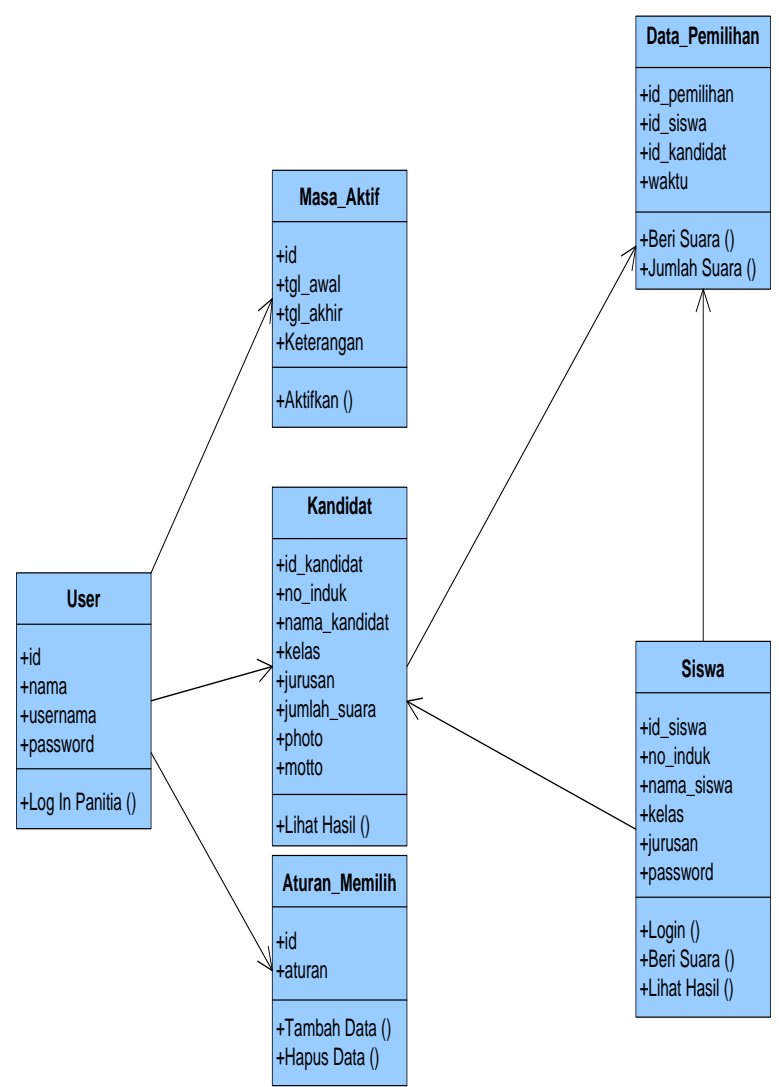

Gambar 6. Diagram Kelas Aplikasi Voting

Gambar 6 Diagram kelas mendeskripsikan jenis-jenis objek dalam sistem dan berbagai macam hubungan statis yang terdapat di antara mereka. Diagram kelas juga menunjukkan properti dan operasi sebuah kelas dan batasanbatasan yang terdapat dalam hubunganhubungan objek tersebut. 


\section{Interface Voting Pemilihan Ketua Osis}

\section{Tampilan Halaman Utama}

\section{a-Voting

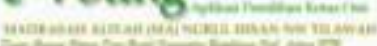

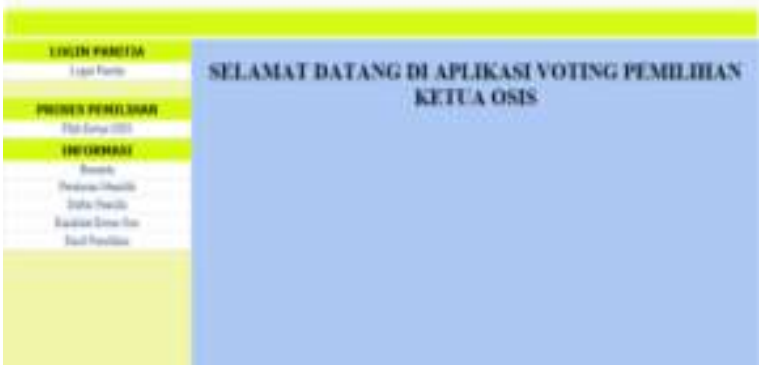

Gambar 7. Halaman Utama Aplikasi Voting

Pada halaman utama ini siswa bisa melihat tata cara memilih, peraturan memilih, daftar pemilih, kandidat ketua osis, hasil pemilihan dan melakukan proses pemilihan ketua osis tanpa melakukan proses login.

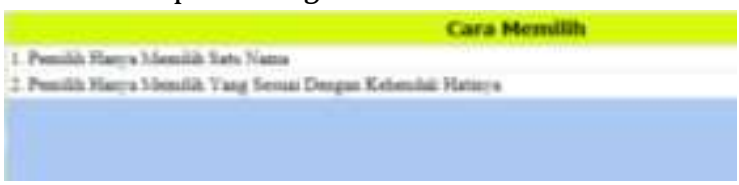

Gambar 8. Tampilan Aturan Memilih

Halaman ini muncul apabila siswa mengklik menu peraturan memilih, untuk melihat daftar pemilih siswa tinggal klik menu data pemilih.

\begin{tabular}{|c|c|c|c|}
\hline $\mathrm{Non}$ & Nana Siswa & Kelas & Junusal \\
\hline 1 & Dne Artesi & $\pi$ & . \\
\hline & EnHuxptrom & $\pi$ & . \\
\hline i. & Elan Seart & $\mathrm{x}$ & . \\
\hline 4 & Elapain & $\mathrm{X}$ & . \\
\hline & ErastabDen & $\mathrm{X}$ & . \\
\hline & Enšętri & $\mathrm{X}$ & . \\
\hline 7 & Heneotiat & $\mathrm{I}$ & . \\
\hline & HowdRtiteh & $\pi$ & . \\
\hline & linaturash & $\mathrm{X}$ & . \\
\hline & IfHired & $\mathrm{I}$ & . \\
\hline & Iftetrilant & $\mathrm{X}$ & . \\
\hline & Jinna & I & . \\
\hline 13. & Watb & $\mathrm{X}$ & . \\
\hline & Jen Datimn & $\mathrm{X}$ & . \\
\hline 15 & Whe BanHaned & $\mathrm{X}$ & . \\
\hline
\end{tabular}

Untuk melihat data kandidat ketua osis tinggal klik menu kandidat ketua osis maka akan tampil halaman berikut

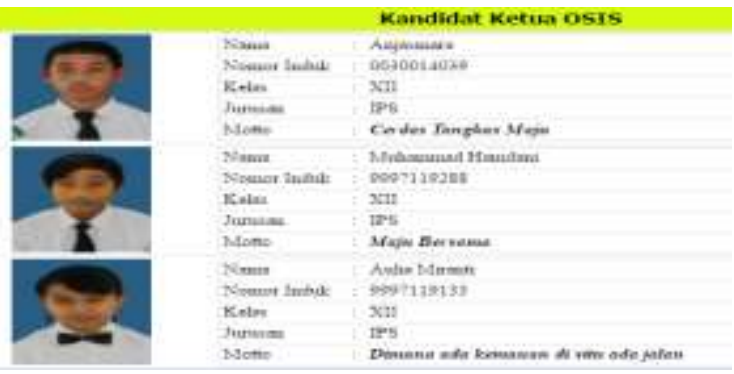

Gambar 10. Halaman Kandidat Ketua Osis

Untuk melihat hasil pemilihan yang telah dilakukan oleh siswa bisa mengklik menu hasil pemilihan

\begin{tabular}{|c|c|c|c|}
\hline \multicolumn{4}{|c|}{ [HASIL PERIIIHAN OSIS SEMENTARA] } \\
\hline Agroun & Oren & I & 1\% \\
\hline Mtrexingin & Ong & I & 19 \\
\hline Ath Urast & $\theta \operatorname{lng}$ & I & $N$ \\
\hline \multicolumn{4}{|c|}{ Total 5iara: :0 } \\
\hline
\end{tabular}

Gambar 11. Halaman Hasil Pemilihan

Untuk melakukan proses voting pemilihan ketua osis pengguna bisa mengkilik tombol pilih ketua osis pada menu proses pemilihan, pengguna akan melakukan proses login terlebih dahulu dengan memasukkan NIS dari masing-masing siswa.

SLAHKAN LOGINUNTUK MELAKUKAN PEVII HAN KETUA OSIS NIS Password

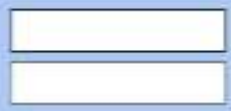

\section{LOGN}

Gambar 12. Halaman Login Siswa

Jika NIS dan password yang dimasukkan salah maka akan ada konvirmasi kesalahan, jika benar maka akan masuk kehalaman masing-masing siswa, untuk melakukan pemilihan siswa tinggal mengklik foto masing-masing kandidat. Penilithan Ketun Osis

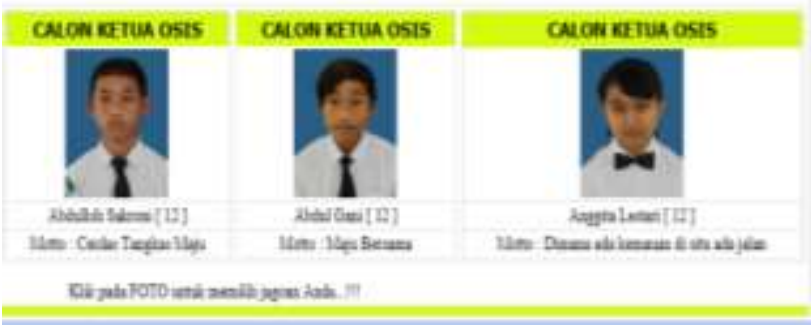

Gambar 13. Halaman Pemilihan Ketua Osis 
7. Kesimpulan dan Saran

A. Kesimpulan

1. Perancangan aplikasi voting pemilihan ketua OSIS pada MA Nurul Ihsan NW Tilawah berbasis web dapat mempermudah proses pemilihan ketua OSIS

2. Dengan adanya aplikasi pemilihan ketua OSIS dapat memberikan hasil voting yang akurat, cepat dan terpercaya serta bisa mengurangi angka siswa yang tidak memilih dan tidak akan mengganggu proses belajar mengajar

\section{B. Saran}

1. Perlu diadakan pelatihan panitia dan siswa, dimana pelatihan tersebut akan memberikan pengarahan kepada panitia dan siswa yang akan dijadikan sebagai pengguna aplikasi.

2. Agar aplikasi pemilihan ketua OSIS ini terus dapat digunakan, maka disarankan supaya selalu diupdate sesuai dengan perkembangan yang ada, termasuk penambahan fasilitas dan fitur sesuai dengan kebutuhan yang ada.

\section{Daftar Pustaka}

Aditya, Alan Nur., 2011, Jago PHP \& Mysql Dalam Hitungan Menit, Dunia Komputer, Bekasi.

Al Bahra Bin Ladjamudin., 2006, Rekayasa Perangkat Lunak, Graha Ilmu, Yogyakarta.

Budi Raharjo. dkk 2010. Modul Pemrograman Web (HTML, PHP, MySQL). Modula Bandung.

Fatta Al Hanif, 2007, Anailis \& Perancangan Sistem Informasi untuk Keunggulan Bersaing Perusahaan \& Organisasi Modern, Andi Yogyakarta.

Hustinawati, Algoritma \& Pemrograman (Flowchart dan Basic) , Universitas Gunadarma (1991)
Hodia, Maelani, and Khairul Imtihan. "Perancangan Sistem Informasi Praktek Klinik Kebidanan (PKK) Pada Prodi DIII Kebidanan Stikes Qamarul Huda." IJNSIndonesian Journal on Networking and Security 6.3 (2017).

Imtihan, Khairul, Rabiatul Hadawiyah, and Hasyim Asyari-STMIK Lombok. "Sistem Informasi Penggajian Guru Honorer Menggunakan Konsep Agile Software Development dengan Metodologi Extreme Programming (XP) pada SMK Bangun Bangsa." IJNSIndonesian Journal on Networking and Security 7.2 (2018).

Khairul Imtihan. "Perencanaan Strategi Sistem Informasi Pendidikan Pada Sekolah Tinggi Manajemen Informatika dan Komputer (STMIK) Lombok." Bianglala Informatika 3.2 (2015).

Nugroho Adi., 2010, Rekayasa Perangkat Lunak Berorientasi Objek dengan Metode USDP, ANDI, Yogyakarta

Risky Yuniarti, 2015, Aplikasi Pendaftran dan Pemilihan Pengurus OSIS SMK Sudirman 1 Wonogiri Berbasis Web, Jurnal Informatika Universitas Muhamadiyah Surakarta.

Rizqi Andhestria Adhi dan Harjono, 2013, Rancang Bangun Sistem Informasi E-Voting Berbasis SMS (Developing E-Voting Information System SMS Based), Jurnal Teknik Informatika Universitas Purwokerto

Yusriannur, M., 2012, Aplikasi E-Voting Berbasis Web Untuk Menunjang Pemilihan Presiden Mahasiswa Pada Universitas Dian Nuswantoro Semarang, Jurnal Sistem Informasi Universitas Dian Nuswantoro Semarang 